\title{
SMART FACTORIES IN THE AGE OF INDUSTRY 4.0
}

\author{
Sandra GRABOWSKA \\ Silesian University of Technology
}

\begin{abstract}
:
Over the last few years, the Industry 4.0 concept (called the Fourth Industrial Revolution) has attracted attention among both academics and practitioners. Industry 4.0 is a very broad domain including production processes, efficiency, data management, relationship with consumers, competitiveness, and much more. Therefore, the aim of the paper is to present new factory archetypes. The manuscript uses a synthesis of literature (scientific studies and industrial reports). Based on the results obtained, the archetypes of factories of Industry 4.0 are described. The presented manuscript contributes to the development of literature on the concept of Industry 4.0. The results obtained from the analysis of the literature not only summarize the existing knowledge about Smart Factories, but also indicate the directions of potential research.
\end{abstract}

Key words: Smart Factories, Industry 4.0, Intelligent automated and robotic factories, Digital mass-individualized factories, Handmade production using digitization

\section{INTRODUCTION}

Industry 4.0 was initiated in 2011 in Germany and has been strongly promoted by the governments of industrialized countries around the world, and leaders in some industries have already implemented pilot cybernetic production systems (production of equipment: household appliances, cars, machinery and equipment). The changes initiated in the 21st century will take place over decades in enterprises, as the creation of new cyber-production solutions will require many investments [28].

The media and literature still dominate the perception of Industry 4.0 in the aspect of technological changes that should be implemented in manufacturing companies, and yet this industrial revolution, its trends and effects are visible in all macro and micro areas of the market. The proposed technological changes, which have gained strategic importance in the thinking and actions of many market players, while penetrating all links in the value chain and ways of their connections, have changed the scope of competition and the way in which consumer needs are met. At the same time, there are dynamic and clear changes in the needs and expectations of modern consumers [34].

One of the key reasons for the Fourth Industrial Revolution called Industry 4.0 is the need to strengthen the competitiveness of Western European economies, which as a result of the progressing globalization process and rising labor costs have seen a decline in their share in global industrial production [23]. The need to improve the competitiveness of local European enterprises and reverse the dangerous trend of relocating enterprises outside Europe, which today results in a deepening decline in the industrialization of European developed countries, prompted German experts to develop a new industry concept that would allow them to regain the status of industrialization leader and control global production trends [44].

The Industry 4.0 concept includes areas that include numerous technologies and associated paradigms. The main elements that are closely related to the idea of Industry 4.0 include: industrial internet of things, production based on the cloud, intelligent factories, cyber physical systems or social product development. In this concept, the production process will continue to be an orderly series of actions thanks to which the customer (user) has the opportunity to obtain a product. It must be designed and organized for set purposes (which may change). It has a dynamic character, which is conditioned by the volatility of quantitative and qualitative characteristics, material, energy and information subsidies. It should be used to maximize corporate profit and customer satisfaction $[38,41]$.

The ubiquitous digitization, development of the Internet and the possibility of collecting and processing huge amounts of data in real time cause that modern enterprises have to increase their competition and 
introduce digitally supported manufacturing technologies, such as Data Mining, Big Data Analytics or ICT systems that enable communication in the machine-machine and human system-machine in a virtual environment of the entire supply chain. According to Industry 4.0 describes the increasing digitization and automation of the manufacturing environment, as well as the creation of digital value chains to enable communication between products, their environment and business partners. Using of advanced digitalization, the combination of Internet technologies and intelligent objects (machines and products) seems to result in a new fundamental paradigm shift in industrial Production [29]. The vision of future production contains modular and efficient manufacturing systems in which products control the systems. This means the use of intelligent mechatronic products (machines, devices, robots, means of transport, etc.) in the entire PLM (Product Life Cycle Management) chain, starting from the creation of a new product concept, virtual documentation, printing 3D models, laboratory tests, manufacturing product in a virtual production environment and its testing, production of a product in a real environment, development of computer-aided production and assembly documentation, logistics, product delivery to the customer and its service up to product recycling [15].

For the first time in the history of humanity, technology, by connecting more and more numerous industries with society, allows to influence the volume and quality of production as well as the functionality of products. Industry 4.0 introduces leading IT solutions in all aspects of production, enabling the creation of not only specific products ordered by customers but also entire related value chains [35]. Thanks to the use of advanced ICT technologies, it is possible to more accurately adapt production to customer expectations while maintaining low costs, high quality and efficiency. New business models and technologies such as artificial intelligence or additive manufacturing accelerate industry transformation processes, changing current business methods and market structure $[16,17]$.

The idea of Industry 4.0 is creating sophisticated enterprise networks connected by intelligent resources communicating via the Internet, using known and already used technologies, including Internet of Things (IoT), Big Data, Cloud Computing, etc. This means that modern enterprises, in order to compete in the modern market must cooperate within cyber-physical systems with other enterprises creating the Cyber Industry networks (CIN) [43].

Thanks to the development of ICT networks, it is possible to create a fully integrated system of suppliers, producers and customers operating in open virtual networks. According to this concept, ICT-based solutions will be integrated with all subsystems, production and logistics processes, system resources and networks of suppliers, producers and customers
[33]. Therefore, newly designed ICT systems will integrate entire supply chains, creating Cyber-Physical Systems (CPS), which are open social engineering systems. CPS systems should ensure the collection of large amounts of data, their processing and impact on physical processes throughout the enterprise network by means of an unlimited number of network connections at the same time with the negligible participation of employees who perform only supervisory functions [42].

In the situation of the development of the Industry 4.0 concept, each company is perceived as offering an intelligent module for use in the entire logistics chain, and the size of the enterprise ceases to be meaningful. Meanwhile, the business model of a particular enterprise takes on the significance of the technology used, the level of highly qualified staff employed and openness to unlimited communication using increasingly common technologies, including cloud computing, big data and Internet of Things $[1,27]$. Industry 4.0 is a very actual topic, not sufficiently researched and poorly recognized by researchers. In 2015, searching the WoS, Scopus and Google Scholar databases, there were only 51 scientific publications with keyword "Industry 4.0". There is still a huge research gap in this area. However, more and more researchers see the need to describe this topic.

The aim of the paper is to present new factory archetypes. Based on the results, answers to research questions were obtained: 1 : What will be the manufacturing companies in the future? 2: What will be the archetypes of factories in the era of the Fourth Industrial Revolution? 3: What will be the attributes of future factories, called Smart Factories?

The paper is organized as follows: Introduction describes the concept of Industry 4.0. The following part presents research methods. The next part of the paper presents archetypes of Smart Factory. The final part of the article put forward conclusions and discussions.

\section{RESEARCH METHOD}

A literature review is an essential part of any research work. The aim of this study was to obtain an overview of archetypes Smart Factory. The manuscript uses a synthesis of literature - scientific research and industrial reports. To answer the questions posed in the manuscript, a bibliometric analysis of publications contained in the Web of Science, Scopus, Google Scholar and other publicly available sources and industrial reports available on the Internet was carried out. The obtained publications were selected by searching their content for new archetypes of factories, modern factories, Smart Factories in the concept of Industry 4.0. Figure 1 shows the applied literature synthesis [26]. With regard to Figure 1, the review procedure consists of three stages, covering planning, searching with selection and analysis of the results obtained. The procedure thus prepared was used in the work. 


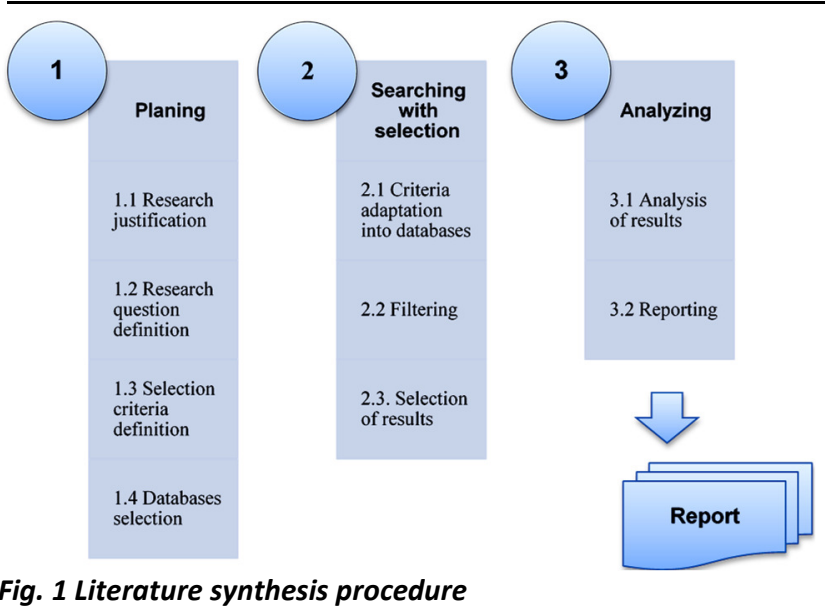

Considering the major objective of the paper, the literature research was justified. The research questions, presented in the Introduction, were used in the literature research in order to define the selection criteria described. The literature and industrial report was selected by the:

- First - various entries, e.g. "Industry 4.0", "Smart Factories", "New Factory Archetypes", "Factory 4.0", "Factory of the Future",

- Second - the same information was selected in particular publications,

- Third - by establishing the basic source of information in particular publications of the authors.

\section{RESULTS}

Based on the literature review, answers to research questions were obtained:

1. What will be the manufacturing companies in the future?

2. What will be the archetypes of factories in the era of the Fourth Industrial Revolution?

3. What will be the attributes of future factories, called Smart Factories?

The archetype is the prototype of a character, motif, pattern or event. In the case of a production plant in times of digital change, archetypes refer to emerging new ideas in which you can see certain patterns, models of factories that differ in how they function $[9,10]$.

Archetypes will differ according to production volume (low or high) and value sources, i.e. personalization or competitive costs [32, 40]. There are four general emerging categories of new generation factories that use different levers of Industry 4.0 value, but with different emphasis depending on the demand segment and the needs to which they relate. Four types of future factories can be distinguished $[7,14]$ :

1. Smart-automated and robotized plants, or Intelligent automated and robotic factories,

2. Digital mass-individualization factories, otherwise known as Customer-centric plants, i.e. customerfocused factories,

3. E-plants in a box, mobile modular factories, i.e. mobile modular factories,

4. Handmade with digital touch, i.e. hand-made production highly supported by digitization.
Intelligent automated and robotic factories

Intelligent automated and robotic factories responding to the demand for mass products, specialize in the implementation of very high production volumes at low costs (lower than the competition), thanks to fully automated and digitized processes $[5,18]$. Production in such a factory takes place on dedicated production lines, having common modules for the packaging of goods (i.e. activities involving the portioning and packaging of products in containers, parcels, shipping sets or retail sales) [11]. Such a model can be adopted, for example, by food production plants, basing their business on cooperation with discount chains, in which case cost competitiveness is very important $[3,6]$.

The supply chain in such a factory will be comprehensively integrated, i.e. it will be implemented in an end-to-end system (a system created by combining all logistics processes and the supply chain, starting from the customer and going up the stream through production, up to our supplier base, and flows are two-way). Such a model will enable full transparency and optimization of the digital thread, which will result in automated and usually uninterrupted processes as well as efficient material flows [22]. In addition, robots that already have the potential for a significant increase in operational efficiency will not only be characterized by higher intelligence, but also greater cooperation and security. Going further, improved collaboration between humans and robots will enable operators to work more safely next to the robots in the production hall. The plant will provide a very high rate of productivity per machine, thanks to the possibility of using predictive maintenance to reduce unplanned downtime and optimize throughput in real time [13].

Finished products from an intelligent automated factory can hit the mass market, while semi-finished products can be a raw material for individualized customer-oriented factories or mobile modular factories [36].

An early example of the archetype of an intelligent automated and robotic factory can be considered the BMW i3 production plant because it has a high level of integration and automation at production sites. The robots do their work at every stage of production, including in the body shop, print shop and assembly shop. Real-time tracking and location of the unfinished product is carried out using RFID technology .Operators have mobile control tablets that are used to monitor and access all necessary data. Finally, factory management is centralized in one main building that acts as the "central nervous system".

\section{Digital mass-individualized factories}

Digital mass-individualized factories focus on production in the scope of large or medium volumes, however, unlike the previous model, they enable full personalization of their products, which makes the products highly individualized. Such products are e.g. cars, clothes, shoes, furniture, gates, decorative elements of the structure. Production lines are prepared in terms of technology and process for the implementation of short or very short 
series, the occurrence of frequent retooling and personalization of products differing in color, additional equipment, texture [25, 39]. Production sockets often take the form of universal modules. Modularization of the production system is based on machines that adapt to various activities and are able to communicate with each other via the Internet. Modular production sockets increase the possibilities of individualization of production. Allow to reduce machine changeover times and increase product personalization so that it meets all customer requirements and mass personalization trends. In this case, the production sequence flow is controlled by the product. This means that it is the product that "decides" which sockets to use to leave the production line in the shortest possible time [45].

Retail demand will evolve over time, driven by a strong trend towards increasing product personalization. How can you serve so many clients in called "Segment of One" approach? A broad approach to marketing and customer engagement with basic segmentation is no longer an effective way to connect with the new generation of consumers. Customer expectations have increased significantly, which means that marketers need to innovate, finding new ways to understand and encourage their customers. "Segment of One" means a change in the way customers segmentation. To be successful, companies must perceive their customers as individuals and not assign them to general demographic categories. Basic segmentation no longer goes far enough because customers have begun to expect a deeper connection with their favorite brands [10]. Putting people first requires marketing to use information collected on the basis of historical customer data (e.g., their preferences, search history on the manufacturer's website, etc.) in order to deeply understand the complex nature of the consumer and the clarity of where the brand should be present in order to most gain value [2].

"Customer oriented plants" are likely to fill a gap in the global, integrated supply chain that already benefits from economies of scale and a personalized approach to production and services. Customers will design their products online. Product will be sent directly to the most suitable factory after ordering. The extremely flexible supply chain will produce in "Batch Size 1" mode (unit production on an industrial scale) run in real time based on customer orders, which will lead to very short lead times. Supply of inputs and semi-finished products will be based on demand-driven demand forecasts. The machines will be designed to minimize the changeover time to adapt to changes in demand, the size of the series produced, specifications and other parameters. Despite the flexibility, the plant will still have to provide very high performance per machine [12].

An example of a modern company with mass individualized factories is Adidas. The manufacturer's website allows customers to design shoes in their own style. Modification begins with the selection of the basic footwear model, along with its type. Then the user of the page chooses one of a wide range of colors, visual decorations of the shoe (e.g. reflections, colored inserts, inscriptions), type of material, type of sole and additional accessories to order (overlays, laces) [19]. The whole process of modifying the basic shoe model allows you to create your dream configuration according to your own taste, as expected by the customer, and to have a product unavailable in the mass offer. This solution allows customers (for an additional fee) to choose such product variants that are missing in the offer of models predefined by the designer.

\section{Mobile modular factories}

Mobile modular factories, i.e. mobile production plants, can be moved from place to place. Mobility means being able to flexibly build, run, package and move such a factory. The reason for portability may be market trends, access to raw material or industry standards [21]. The problem is how can you deal with niche subscales and distant markets, such as growing but very fragmented African markets?

A mobile modular factory, otherwise known as "E-plant in a box", reinforced by Industry 4.0 levers, such as 3D printing, flexibility of production machines, is a lowcapitalization installation and can be quickly configured in new locations at competitive costs. Typically, factories in this archetype take on minimal size and small scale. The plants are able to produce a certain amount of products in any location in a short time, on the production hall or directly next to it, for the duration of the order.

Factories can potentially be delivered in containers. In its final version, the e-plant in a box can serve customers passing by and stopping to design their own product, on site, with the help of specialists. They could choose structures and materials, use simulation tools, and then come back to pick up their product at the plant. Therefore, the plant will adapt very well to local trends due to the proximity of customers and the local ecosystem, and moreover, the time to market will also be reduced due to the proximity of suppliers and customers. The plant can only be automated to a small extent, but operators will use Industry 4.0 technologies to make manufacturing easier for them. For example, an exoskeleton, which uses human-robot cooperation, could, for example, relieve employees of heavy loads, as well as be a light and relatively inexpensive tool. Another example of technology facilitating work in mobile factories is a flexible production system with robots operating in the "plug and play" system, performing specific tasks in which the participation of robots would give the greatest benefits. 3D printing can be used for the production of spare and custom parts, thus reducing the needed inventory, while reducing transport costs and bypassing the import tariffs of raw materials or semi-finished products [4].

Customer analysis takes place thanks to the comprehensive flow of information in the "end-to-end" mode. Highly qualified central teams support process improvement, design and maintenance. Finally, the mobile production plant is integrated into the surrounding ecosystem, e.g. it produces its own energy, so it doesn't have to be in an industrial zone. It may be close to 
shopping centers and other areas convenient for customers.

An example of such a mobile production plant may be mini factories producing tools and components for the implementation of large construction projects. They can be located directly, in the vicinity or on the construction site [10].

A more advanced factory was presented by Nestlé in cooperation with Concept Consult Architects, it is a modular dairy. The project of a new type of modular factory created by the Swiss food manufacturer Nestlé can be built in half the time of the traditional, up to $50 \%$ to $60 \%$ of the cost. Unique in terms of value chain, the concept is based on the principles of Industry 4.0, it is fully modular and decentralized. Standardized building structure elements were proposed. Solar panels for water heating and electricity generation, ready-made room furnishings in the form of canteens, halls, etc. Standardization enables standardization in the area of design and construction of industrial plants in countries that lack industrial infrastructure [9]. In these countries, this concept will help the company quickly leave its hallmark and create local jobs, bringing them closer to customers and raw materials. The modular concept of the factory has so far been developed to industrialize simple processes such as repackaging and mixing dry goods (e.g. bouillon cubes) instead of creating more complex products [8].

\section{Handmade production using digitization}

The idea of manual production using digitization applies to very high quality products created in unit quantities. These can be goods located in a niche market segment (e.g. aeronautics, military), but also luxury goods (e.g. luxury cars). Factories employing craft production using digitization employ top-class employees who, being professionals, are able to combine manual work with modern tools and technologies. Specialists processing materials fulfill individual customer orders [31, 37]. The use of the latest technologies in this type of factory allows to increase work safety, elements of this technology can replace the manual process at a certain stage of the production process, in which a person is much less effective than a robot or the performed activity may endanger human health, an example may be a robotic paint shop in factories automotive industry. Technology support greatly facilitates the organization of work and the circulation of information, and thus reduces production time and allows you to maintain the highest quality product to satisfy even the most demanding customers [14, 20, 24].

\section{DISCUSSIONS AND CONCLUSION}

Based on research recognize each of the archetypes of a modern factory has unique features. Each Smart Factory should interact with the customer to a greater or lesser extent, strive to exchange information and increase trust in the company, enable simple ways of ordering the desired product, which greatly facilitates the Internet of Things. Other common issues that apply to every modern factory archetype are:
- development of competences and training of managers, line employees and engineers,

- caring for operational perfection, continuous improvement,

- development of digital networks and information flow infrastructure,

- ensuring cyber security of the entire company by using appropriate security policies and tools.

Industry 4.0 has become more and more important for industry in recent years. The implementation of modern technology, techniques and management methodologies specific to Industry 4.0 should cover the entire production process as well as management processes. One can put forward the thesis that only in such a case there will be a sufficiently strong effect of complementarity and synergy, necessary in the world of the fourth industrial revolution for the transformation of the examined enterprise from its current status to Smart Factory.

Industry 4.0 makes it possible to interlink all elements related to manufacturing processes. The main target is the connection between the real physical world and the digital factory - creating Smart Factory.

Summing up Intelligent Factories in the era of Industry 4.0, it should be noted that it is difficult to predict now how the concept of Industry 4.0 will develop and how it will proceed. That's why the final kind of Smart Factories will be known only in the future.

Formulating and adapting to changes is a long-term activity that requires a lot of material and financial expenses. This increases the need for future research into the problems of creating Smart Factories, especially focused on network forms of cooperation between customer-oriented enterprises operating in the era of the Industry 4.0 concept.

\section{ACKNOLEGEMENT}

This paper has been elaborated when solving the grant BKM-588/RMO/2019; 11/990/BKM_19/0069

\section{REFERENCES}

[1] C. Arnold, D. Kiel, KI. Voigt. „How Industry 4.0 changes business models in different manufacturing industries": In: ISPIM conference proceedings. International Society for Professional Innovation Management (ISPIM), 2016, p 1.

[2] ASTOR - Industry 4.0 Whitpaper. Internet: www.astor.com.pl/industry4 [Feb. 10, 2020].

[3] B. Gajdzik, S. Grabowska. "Business models in enterprises 4.0 - an attempt to identify the assumptions used to determine new business models." Enterprise Management, 33(21), pp. 2-8. 2018. DOI: 10.25961/ent.manag.21.03.01. Avalaible: http://www.zp.ptzp.org.pl/wp-content/uploads /2019/01/18_3_1.pdf [Nov. 14,2019]

[4] M. Bakkari, A. Khatory. "Industry 4.0: strategy for more sustainable industrial development in SMEs". Internet: http://ieomsociety.org/ieom2017/papers/414.pdf [Feb. 10, 2020].

[5] T. Bauernhansl. „Die Vierte Industrielle Revolution - Der Weg in ein wertschaffendes Produktionsparadigma". In T. Bauernhansl, M. ten Hompel, \& B. Vogel Heuser (Eds.), Industrie 4.0 in Produktion, Automatisierung und Logistik Anwendung, Technologien, Migration 2015, pp. 5-35. Wiesbaden: Springer. 
[6] R. Berger. "The Industrie 4.0 transition quantified. How the fourth industrial revolution is reshuffling the economic, social and industrial model". Roland Berger, Monachium 2016.

[7] D. Stephens. The Retail Revival: Reimagining Business for the New Age of Consumerism. Wiley, 2013, p. 195, ISBN: 978-1-118-48967-3.

[8] D. Zaraziński, P. Szymczak. "W stronę przemysłu 4.0." Avalaible: https://www.astor.com.pl/industry4/HBRP_ASTOR _w_strone_przemyslu_4_0.pdf [Nov. 10, 2019].

[9] Deloitte. "How leaders are navigating the Fourth Industrial Revolution". Internet: https://www2.deloitte.com/us/en/ insights/deloitte-review/issue-22/industry-4-0-technology manufacturing-revolution.html [Feb. 10, 2020].

[10] G. Erboz. "How to define Industry 4.0: The Main Pillars of Industry 4.0". Internet: https://www.researchgate.net/ publication/326557388_How_To_Define_Industry_40_Main_Pillars_Of_Industry_40 [Feb. 10, 2020].

[11] European Commission. "Factories of the future. Multi-annual roadmap for the contractual under Horizon 2020." Avalaible: https://www.effra.eu/sites/ default/files/factories_of_the_future_2020_roadmap.pdf [Nov. 10, 2019].

[12] H. Fatorachian, H. Kazemi. "A critical investigation of Industry 4.0 in manufacturing: theoretical operationalisation framework". Journal Production Planning \& Control. The Management of Operations, Volume 29, 2018, Issue 8, pp. 633-644, Avalaible: https://DOI.org/10.1080/09537287.2018.1424960 [Feb. $10,2020]$

[13] F. Fogliattoa, S. da Silveirab, D. Borensteinc. "The mass customization decade: An updated review of the literature". International Journal of Production Economics 138 (1), 14-25, 2012. DOI: 10.1016/j.ijpe.2012.03.002.

[14] G. Chmielarz."Present State And Future Application Of Smart Technologies In Manufacturing Processes". Production Engineering Archives, 24 (2019), pp.14-19, DOI: 10.30657/pea.2019.24.04

[15] S. Grabowska, B. Gajdzik, S. Saniuk. "The Role and Impact of Industry 4.0 on Business Models". In: Grzybowska K., Awasthi A., Sawhney R. (eds) Sustainable Logistics and Production in Industry 4.0. EcoProduction (Environmental Issues in Logistics and Manufacturing). Springer, 2020 Cham. Avalaible: https://doi.org/10.1007/978-3-03033369-0_3 [Feb. 10, 2020].

[16] H. Hirsch-Kreinsen. “Wandel von Produktionsarbeit - „Industrie 4.0". Soziologisches Arbeitspapier, No 38, Dortmund 2014.

[17] H. Kagermann, W. Wahlster, J. Helbig (eds.). Recommendations for implementing the strategic initiative Industrie 4.0: Final report of the Industrie 4.0 Working Group. Industrie 4.0: Mit dem Internet der Dinge auf dem Weg zur 4. industriellen Revolution, VDI-Nachrichten, April (2011).

[18] H. Lasi, P. Fettke, H.G. Kemper, T. Feld, M. Hoffmann. "Industry 4.0", Bus. Inf. Syst. Eng. 6, 2014, pp. 239-242. DOI: 10.1007/s12599-014-0334-4.

[19] M. Hermann, T. Prentek, B. Otto. "Design Principles for Industrie 4.0 Scenarios: A Literature Review". Avalaibe: http://www.iim.mb.tu-dortmund.de/cms/de/forschung/Arbeitsberichte/Design-Principles-for-Industrie4_0-Scenarios.pdf [Feb. 10, 2020].
[20] J. Gracel, M. Stoch, A. Biegańska. "Industry 4.0 engineers (not) ready for change?". Avalaible: https://www.astor.com.pl/images/Industry_4-0_Przemysl_4-0/ASTOR_Inzynierowie_4.0_whitepaper.pdf [Nov. 10.2019].

[21] J. Lee, B. Bagheri, H.A. Kao. "A Cyber-Physical Systems architecture for Industry 4.0-based manufacturing systems". Manufacturing Letters, 3, 2015, pp. 18-23. DOI:10.1016/j.mfglet.2014.12.001.

[22] J. Müller, D. Kiel, K. Voigt, "What Drives the Implementation of Industry 4.0? The Role of Opportunities and Challenges in the Context of Sustainability." Sustainability 2018, 10, 247. DOI: $10.3390 /$ su10010247.

[23] K. Wheeler. "How a 'segment of one' approach can help businesses connect with their customers". Internet: https://www.fourthsource.com/general/how-a-segmentof-one-approach-can-help-businesses-connect-with-theircustomers-23392 [Nov. 12.2019].

[24] K. Zhou, T. Liu, L. Zhou. "Industry 4.0: Towards Future Industrial Opportunities and Challenges" Tang, $Z$ and Du, J and Yin, $\mathrm{S}$ and $\mathrm{He}$, L and Li, R (Ed.), 2015 12th International Conference on Fuzzy Systems and Knowledge Discovery (FSKD). pp. 2147-2152.

[25] S. Kamble, A. Gunasekaran, S. Gawankar. „Sustainable Industry 4.0 framework: A systematic literature review identifying the current trends and future perspectives". Process Safety and Environmental Protection, 117, 408425, http://doi.org/10.1016/j.psep.2018.05.009

[26] B. Kitchenham. „Procedures for performing systematic reviews". Keele, UK, Keele University, 33, 1-26. Avalaible: http://www.it.hiof.no/ haraldh/misc/2016-08-22-smat/ Kitchenham-SystematicReview-2004.pdf [Feb. 11, 2020].

[27] J. Lee, H-A. Kao, S. Yang. "Service innovation and smart analytics for Industry 4.0 and big data environment". Procedia CIRP 2014 16:3-8.

[28] M. Hermann, T. Pentek, B. Otto. "Design principles for industrie 4.0 scenarios", Proceedings of the Annual Hawaii International Conference on System Sciences 2016, pp. 3928-3937. DOI:10.1109/HICSS.2016.488.

[29] M. Imran, W. Hameed, A. Haque, "Influence of Industry 4.0 on the Production and Service Sectors in Pakistan: Evidence from Textile and Logistics Industries". Social Sciences 2018, 7, 246. DOI: 10.3390/socsci7120246.

[30] M. Ingaldi, R. Ulewicz. "Problems with the Implementation of Industry 4.0 in Enterprises from the SME Sector", Sustainability, 2020, 12, 217.

[31] M. Olszewski. "Mechatronizacja produktu i produkcji przemysł 4.0." Pomiary Automatyka Robotyka, vol. 20(3), ISSN 1427-9126, 2016.

[32] M. Piccarozzi, B. Aquilani, C. Gatti, "Industry 4.0 in Management Studies: A Systematic Literature Review". Sustainability 2018, 10, 3821. DOI: 10.3390/su10103821.

[33] McKinsey. "Industry 4.0 How to navigate digitization of the manufacturing sector". Internet: http://www.forschungsnetzwerk.at/downloadpub/mck_i ndustry_40_report.pdf [Nov. 17, 2019].

[34] N. Szozda. "Industry 4.0 and its impact on the functioning of supply chains". Uniwersytet Ekonomiczny. LogForum, Wrocław, 2017, e-ISSN 1734-459X.

[35] P. Maresova, I. Soukal, L. Svobodova, M. Hedvicakova, E. Javanmardi, A. Selamat, O. Krejcar, "Consequences of Industry 4.0 in Business and Economics". Economies 2018, 6, 46. DOI: 10.3390/economies6030046. 
[36] PwC. "Industry 4.0". Internet: https://www.pwc.pl/pl/pdf /przemysl-4-0-raport.pdf [Feb. 10, 2020].

[37] PWC. „Industry 4.0: Building the digital enterprise Metals key findings. Global Industry 4.0 Survey $2016^{\prime \prime}$. Internet: https://www.pwc.com/gx/en/metals/pdf/industry-4.0metals-key-findings.pdf [Feb. 10, 2020].

[38] R. Nováková, J. Šujanová, N. Nováková. “Improving Quality Management - The Way Toward Economic Prosperity And Quality Of Life", Production Engineering Archives, 24(2019), pp. 10-13, DOI: 10.30657/pea.2019.24.03

[39] R. Ulewicz, M. Mazur. "Economic Aspects of Robotization of Production Processes by Example of a Car Semi-trailers Manufacturer", Manufacturing Technology, Vol. 19, No. 6, 2019, pp. 1054-1059.

[40] M. Rüßmann, M. Lorenz, P. Gerbert, M. Waldner, J. Justus, P. Engel, M. Harnisch. "Industry 4.0: The Future of Productivity and Growth in Manufacturing Industries". Avalaible: www.inovasyon.org/pdf/bcg.perspectives_Industry.4.0_2015.pdf [Feb. 10, 2020].

[41] S. Grabowska. "Improvement of the heat treatment process in the industry 4.0 context." METAL 2018. 27th International Conference on Metallurgy and Materials, May $23^{\text {rd }}-25^{\text {th }}, 2018$, Brno, Czech Republic. Ostrava: Tanger, 2018, pp. $1985-1990$.

\section{Sandra Grabowska}

ORCID ID: 0000-0002-0478-3466

Silesian University of Technology Faculty of Materials Engineering Department of Production Engineering ul. Krasińskiego 8, 40-019 Katowice, Poland e-mail: sandra.grabowska@polsl.pl
[42] S. Saniuk. „The Platform for Production Capacity Exchange Management as a Support for Implementation of the Industry 4.0 Concept". In: Cagáňová D., Horňáková N. (eds) Mobility Internet of Things 2018. Mobility IoT 2018. $\mathrm{EAl} /$ Springer Innovations in Communication and Computing. Springer, Cham 2020.

[43] S. Saniuk, A. Saniuk, D. Cagáňová. “Cyber Industry Networks as an environment of the Industry 4.0 implementation." Wireless Networks, pp. 1-7, ISSN: 1022-0038, e-ISSN: 1572-8196. 2019. DOI: 10.1007/s11276-019-02079-3.

[44] S. Yang, J. Kaminski, H. Pepin, "Opportunities for Industry 4.0 to Support Remanufacturing". Applied Sciences 2018, 8, 1177. doi: 10.3390/app8071177

[45] T. Stock, G. Seliger. "Opportunities of Sustainable Manufacturing in Industry 4.0", Procedia CIRP, 2016, pp. 536541. DOI:10.1016/j.procir.2016.01.129. 